\title{
Hybridity of social enterprise models and ecosystems
}

\author{
Laima Okuneviciute Neverauskiene \\ Faculty of Business Management, \\ Vilnius Gediminas Technical University, \\ Lithuania \\ Laima.Okuneviciute.Neverauskiene@vilniustech.It \\ ORCID 0000-0002-7969-3254
}

\section{Irena Pranskeviciute}

Lithuanian Centre for Social Sciences,

Lithuania

Irena.Pranskeviciute@dsti.lt

ORCID 0000-0001-8734-521X

\begin{abstract}
The growth and development of social enterprises in the world represent a dynamic paradigm shift from the dualistic "market vs. state" and "private vs. public" institutional tradition towards more complex hybrid socioeconomic models, such as social enterprise. A number of research demonstrated the systemic impact of social enterprises on economic sustainability, regional development, and innovations. However, there is a lack of empirical studies, investigating the conditions in which social enterprises evolve. The presented research seeks to analyze how hybridity operates and manifests through social enterprises (microlevel) and the social enterprise ecosystem (macrolevel) in the three post-soviet countries: Ukraine, Lithuania, and Latvia. The research determines that hybridity is a significant factor to social enterprises and social enterprise ecosystem identity and development. This hybridity has a direct relation to sustainability, innovativeness, and efficiency of social enterprises. The analysis of social enterprise ecosystems shows that hybridity frames the supportive environment to social enterprise sector development through crosssectoral collaboration. The study indicates that enablement of the social enterprise sector requires an understanding of a complex and non-dualistic socioeconomic perspective.
\end{abstract}

Keywords: Hybridity, social enterprise, social economy, ecosystem.

JEL Classification: D21, H23, J21, O15, D62, P43

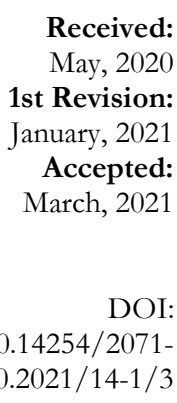

$8330.2021 / 14-1 / 3$ 


\section{INTRODUCTION}

The phenomenon of hybridity originates in evolutionary biology (McMullen, 2018) and refers to the development of new forms or identities, born from the creative interplay of different arrangements, cultures, action logics or characteristics (McMullen, 2018; Sepulveda, 2014; Sivesind, 2017; Defourny \& Nyssens, 2017). Recently, scientists have been observing the expansion of hybrid organizational arrangements through various sectors and markets, in particular in public services, healthcare, elderly care education and also in business fields related to co-production (Pestoff, 2014; Vickers, 2017) and social lean production (Signoretti \& Sacchetti, 2020). Bilan et al. (2016) underlined social enterprise being a significant facilitator of sustainable development. Dinçer with colleagues (2018) analysed hybrid decision-making in the internationalization of firms. The hybridity concept is also broadly elaborated in the socioeconomic context, particularly, in relation to social enterprises (Szymanska \&Jegers, 2016; Defourny, 2017; Besley \& Ghatak, 2017). However, most studies explore hybridity as the social enterprise model peculiarity (Alter, 2007; Grassl, 2012; Defourny, 2014), while only a few studies investigate contextual socioeconomic factors facilitating social enterprise development (Bilan et al., 2016; Kochlami et al., 2020). There is still a lack of empirical studies taking the macrolens and analyzing how hybridity is manifested and can be systemically elaborated on the ecosystem level. Such a large-scale perspective is especially important in the context of growing policymakers' and social investors' attention to social enterprises' impact and role within global sustainability.

The presented research seeks to analyze how hybridity operates and manifests through social enterprises (microlevel) and social enterprise ecosystem (macrolevel) in the three post-soviet countries: Ukraine, Lithuania, and Latvia. There are a lot of empirical studies about social enterprise types, models and development ecosystem, however, the Eastern Europe region is poorly researched in this direction (Staicu, 2017; O'Byrne, 2014). The social enterprise development in the post-soviet countries has different historical, cultural and political context, and knowledge of the wider systemic factors, ecosystems that determine the models of social enterprises that emerge in a given context (Hazenberg, 2016) need more comparative research.

The empirical study of social enterprises showed that hybridity influences the effectiveness, sustainability, and innovativeness of social enterprises. On the other hand, it discovered that the hybrid model, which relates to social enterprise identity, indeed is not a precondition, but rather an aim. Social enterprises often evolve from traditional for-profit or non-profit sectors, through the transformational journey that explores various business logic and discovers or creates integrated, socioeconomic models. Such a dynamic approach to hybridity is important for financial support instruments, legal frameworks or social enterprise entitlement mechanisms because it controverts decisions to define clearer borders for social enterprise definition.

The comparative analysis of four national social enterprise ecosystems discovered three general characteristics, enabling or limiting the systemic social enterprise development: the level of governance centralization, society's ability to self-organize and socioeconomic hybridity. Different combinations of the characteristics form particular patterns in the internal eco-system logic (Meadow, 2008), which, in their turn, influence social enterprises' preferred models and behavior. In the countries with high governance centralization and limited abilities of the society to self-organize (such as Lithuania), social enterprises often expect top-down incentives. Hence, in the ecosystem with a high level of governance centralization, and strong society's abilities to self-organize, the initiatives emerge in a bottom-up manner, but are fragmented and localized (Ukraine).

The research highlights the need for more systemic understanding and individual fine tuning of the incentives of both national and particularly international scope. The support instruments with rigid and 
narrow social enterprise definitions, specific goals oriented or eligible to certain enterprise models limit social enterprise developmental abilities. The interventions, aiming to expand the social enterprise sector can have a more systemic, long-lasting impact if they are oriented on the ecosystem development, therefore stimulate the emergence of missing actors or behaviors, support the creation of cross-sectoral collaboration and self-support networks (Jacobides, 2018; Hazenberg, 2016).

The paper is structured as follows. Section 2 sets the theoretical context by reviewing the literature on the hybridity characteristic in the social enterprise context and defines social enterprise ecosystem characteristics. Section 3 follows with the explanation of the methods used for data collection and analysis. Further, the article analyses the characteristics and the types of social enterprise ecosystems and discusses how ecosystem characteristics reflect on social enterprise development. At the end, we discuss the contribution to theory, policy and research practice and thus conclude.

\section{SCIENTIFIC CONTEXT}

\subsection{Hybridity in social enterprise models}

The term „hybrid“ organization is used to describe a wide array of business models (Eldar, 2017; Alter, 2007; Grassl, 2012). Such organisations are charities, running business to "commercial non-profits", like hospitals, schools, elderly care centers, which by the legal form are non-profit entities, but by the mission and business model are commercial or "low-cost sellers", who sell goods or services to low income customers on prices lower than the market price. The spread of hybrid organizational forms represents a broader trend of fading divisions between market and state (Grassl, 2012).

Galera and Borzaga, 2009 argue, that social enterprise influenced the theoretical concept of enterprise in general: the conception of enterprises as organizations promoting the exclusive interests of their owners is questioned by the emergence of social enterprises supplying general-interest services and goods in which profit maximization is no longer an essential condition.

The figure 1 visualizes scientific discourse on social enterprise models and highlights the elements of organizational dynamics, where the amalgamation of social and economic practices is identified, they are motives, assets, accountability, governance, and surplus. It illustrates, how the interplay of social and economic logic presents in a broad variety of forms and models along the scope between two polarities and the biggest overlap emerge through hybrid socio-economic models of social enterprises. 


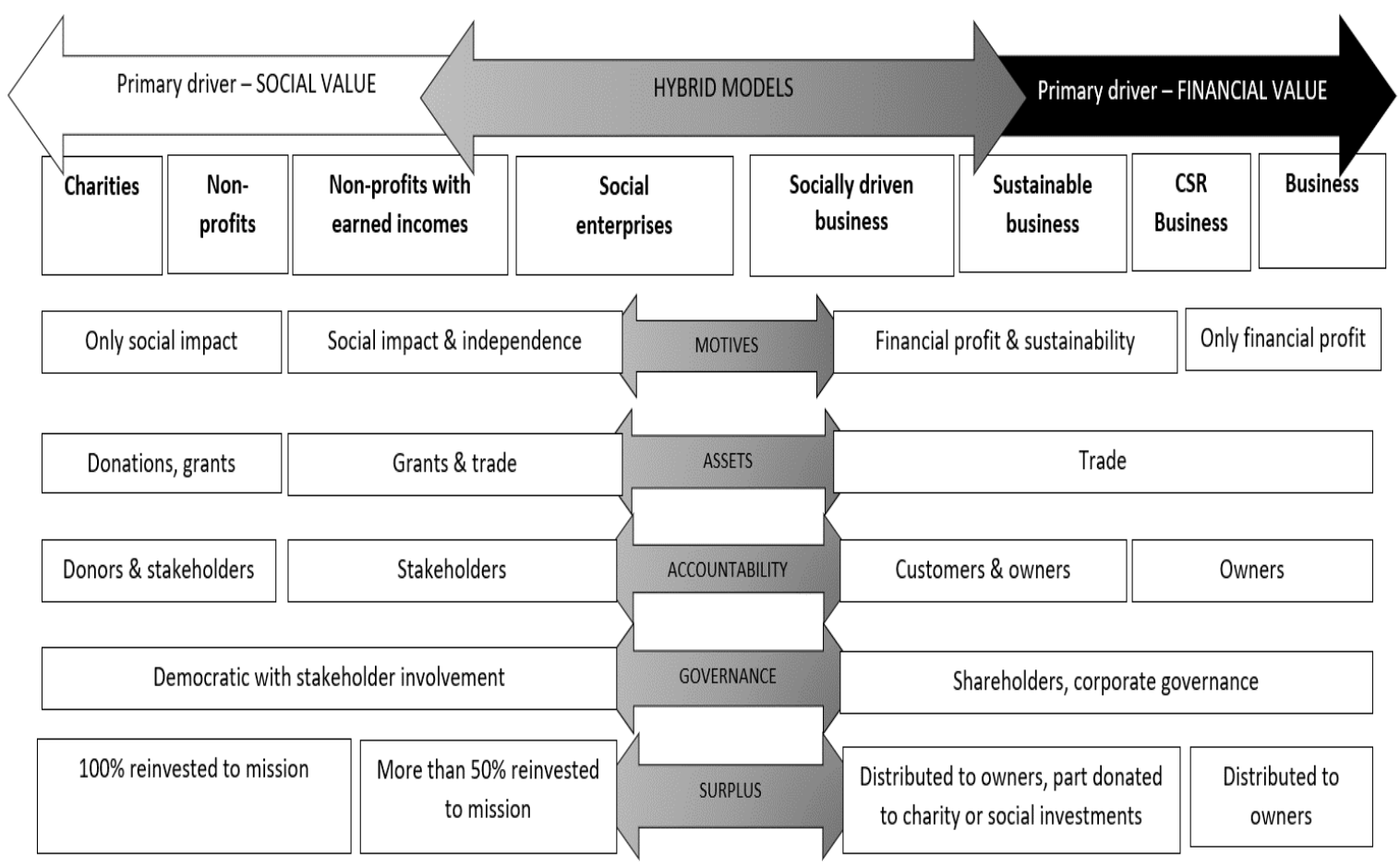

Figure 1. The spectrum of socio-economic hybridity

Source: compiled by authors

(According to Alter, 2007; Grassl, 2012; Defourny and Nyssens, 2017; Eldar, 2017; Szymanska \& Jegers; 2016, Pestoff, 2014)

Social Enterprises are broadly called as hybrid organizations: "mishmash" of legal forms (Young, 2012; Eldar, 2017), mixture of different stakeholders (Szymanska \& Jegers, 2016), various combination of resources and institutional logics (Defourny \& Nyssens, 2017), interplay between profit and social impact objectives (Besley \& Ghatak, 2017), activities combining the characteristics of social work and business (Artcer et al., 2016), creating blended value, which includes both social and financial outcomes (Dao et al., 2017). Nevertheless, hybridity as an integration of different logics is a source of innovation (Vickers, I., 2017) and a driver to competitiveness, sustainability, efficiency and professionalization (Pestoff, 2014; Kim et al., 2020).

The hybridity can cover all key aspects of the organisation's behaviour or can manifest in few of them, the intensity of hybridity also can be different, from full amalgamation of dualities to negotiated links, thus forming broad variety of different types of social enterprise models (Alter, 2007; Grassl, 2012; Eldar, 2017). The forms and intensity of hybridity may flexibly shift reacting to external and internal feedback loops or developmental stage and scaling approach of the enterprise (Bauwens et al., 2020). Therefore, any rigid definition of eligibility characteristics to social enterprise applied by donors, legal frameworks or entitlement procedures don't picture the living variety of social enterprise species, contrary, - they force the social enterprise to adjust their natural behavior to fit in the theoretical framework (Table 1). 
Aspects of social enterprise hybridity

\begin{tabular}{|l|l|}
\hline $\begin{array}{l}\text { The overlap between the third sector and major social institutions like the state, market, and } \\
\text { community (Defourny \& Nyssens 2010; Pestoff, 2014; Artcer et al., 2016) }\end{array}$ & Sectors \\
\hline $\begin{array}{l}\text { Simultaneously operate in two distinct organizational fields: social services and the market } \\
\text { (Garrow \&YeHasenfeld, 2014) }\end{array}$ & Markets \\
\hline Functions as both social service and a commercial production system (Thornton \& Ocasio, 2008) & Systems \\
\hline $\begin{array}{l}\text { Clients are simultaneously both the recipients of social services and production workers in the } \\
\text { business enterprise (Garrow, 2013; Marquis \& Park, 2014; McMullen \& Bergman, 2018) }\end{array}$ & Customers \\
\hline $\begin{array}{l}\text { Governance relies on citizen participation and new forms of democracy: coproduction, } \\
\text { comanagement and governance (Pestoff, 2014; Szymanska \& Jegers, 2016). }\end{array}$ & Governance \\
\hline $\begin{array}{l}\text { The multicriteria decision making approach is suitable for the decision making due to } \\
\text { complexity of socio-economic issues (Dinçer et al., 2018) }\end{array}$ & Decision \\
\hline $\begin{array}{l}\text { Blended value at the organizational level, balancing the creation of financial, social and } \\
\text { environmental wealth (Zahra et al., 2016; Agafanow, 2014; Dao et al., 2017) }\end{array}$ \\
\hline $\begin{array}{l}\text { Amalgamation of the traditional charity and business forms that reconcile multiple sources of } \\
\text { funding (Conger et al., 2018; Wry \& York, 2017) }\end{array}$ & Value \\
\hline $\begin{array}{l}\text { Different scaling strategies are shaped by the organizational mission, encompassing social, } \\
\text { economic, environmental interest orientation (Bauwens et al., 2020) }\end{array}$ & forms \\
\hline $\begin{array}{l}\text { Dual organizational objectives, combining social welfare logic of a charity and the market } \\
\text { efficiency logic of business (Battilana \& Lee, 2014; Besley \& Ghatak, 2017) }\end{array}$ & Goals \\
\hline $\begin{array}{l}\text { Integrated (social, economic, environmental) or hybrid identity, implemented through mixed } \\
\text { financing and multiple objectives (McMullen, 2018, Cornelissen et al., 2020) }\end{array}$ & Identity \\
\hline $\begin{array}{l}\text { A commercial enterprise that channels monetary or other contribution of value to beneficieries } \\
\text { (Eldar, 2017) }\end{array}$ & Capital \\
\hline $\begin{array}{l}\text { Innovations, arising from synergistic interply between different logics: incumbent public sector, } \\
\text { the market responses to increasing competition and civil society, emphasising social value and } \\
\text { democratic engagement (Vickers, 2017) }\end{array}$ & Innovations \\
\hline
\end{tabular}

Source: compiled by authors

Relying on our scientific and empirical observations, we argue for an alternative approach, that socialeconomy hybridity is a process and an aim of the social enterprise, solves many political and scientific discussions around the definition of social enterprise characteristics and criteria. Such an approach offers a common ground around a variety of legal forms and threshold requirements, negotiated by social entrepreneurs and social investors.

\subsection{Characteristics of social enterprise ecosystems}

Over the last decade researchers and policymakers show high interest in the concept of "ecosystems" as a novel and systemic approach to assess and stimulate competitive business environments (Jacobides, 2018), innovations (Adner, 2012; Adner \& Feiler, 2017) and higher value creation (Adner \& Feiler, 2017). The concept of entrepreneurial ecosystems applies the key properties of complex adaptive systems found in biology and social dynamics (Peltoniemi \& Vuori, 2004; Iansity, 2004; Jucevicius \& Grumadaite, 2014) hybridity reflected through high diversity of autonomous actors (Pratono \& Sutani, 2016; Martin \& Osberg, 2015), interrelation (Adner, 2017; Talmar et al., 2019), self-organisation (Dedeurwaerdere, 2017) and cocreation of mutual value (Jacobides, 2018).

The growing researchers and policy-makers attention to positive social enterprise impact encourage design of legal frameworks and financing strategies and institutional arrangements aiming to accelerate the sector (Bretos, et al., 2020). In 2014 and 2018-2019 European Commission in partnership with the leading research institutes in the field of social enterprise, Euricse and EMES published international research, which analyse national ecosystems of social enterprises, map social enterprise universe and spotlights the 
peculiarities of the national environment were social enterprise sector evolves. However, comparative theoretical research on social enterprise ecosystem, its characteristics, types and forming factors remains under-researched. (McMullen, 2018; Hazenberg et al., 2012; Mayer, 2016).

The ecosystem approach, explored in the article, seeks to, understand complex nature of social enterprise development, which evolves in the bottom-up manner, as a response to market, state and community failures, adopts hybrid enterprise models and invoke cross-sectoral collaboration

Social enterprise ecosystem studies unveil, that countries and regions employ different concepts, legal forms and legal frameworks, regulation and unique combinations of actors which historically formed in the bottom-up or top-down manner influenced by the specific socio-political environment (Pratono, 2016; Kwon et al 2018; Ridley-Duff \& Bull, 2016; Roy, 2015; Blundel \& Nyon, 2015; Mason \& Moran, 2018).

Hazenberg (2016) identified four types of social enterprise ecosystems, which form between polarities of state vs. private and international vs. local. Type A-Statist Macro social enterprise ecosystem is characterised by strong dependence on state and international institutions funding. This type relevant to states with centralized nature of governance. Such ecosystems are highly homogeneous in the scope of activities, legal forms and social enterprise models and lack local and self-organization initiatives, bottom-up networks. Type B-Statist Micro-social enterprise ecosystem rely on local institutional policies and are more common to decentralized states. This ecosystem is highly framed by the local community or municipality interests and is characterized by a variety of scopes, concepts, models as well by high heterogeneity among regions. Type $C$ - Private Macro ecosystem is largely formed by private initiative, social investment funds, private hubs and accelerators, and state intervene as a political enabler, but does not provide significant funding. Such an ecosystem is characterized by strong market orientation and domination of social business models. Type $D$ - Private Micro-social enterprise ecosystem has a low level of state funding and rely upon market mechanisms and capacities of civil society to self-organize. The social enterprise development in such an ecosystem is driven by local, regional associations, movements and funding bodies which are independent from state or municipal institutions. Such context creates a heterogeneous ecosystem, with less relationship between social enterprise and state, other third sector or business structures.

Application of the Hazenberg's typology to social enterprise ecosystem analysis helps to identify particular patterns, characteristics and to map the ecosystem's strength and developmental opportunities. Hence this typology does not include socio-economic hybridity, which is an essential characteristic of the social enterprise model. Generally, socio-economic hybridity is broadly researched on micro-level to identify different types of social enterprise models (Alter, 2007; Grassl, 2012; Defourny \& Nyssens, 2017; Borzaga, 2016), but the interplay of social and economic logic on macro-level, ecosystem level, lack of scientific attention.

\section{RESEARCH METHODOLOGY}

The study was implemented in the period from 2017-2019 by the authors of the article and concluded two stages, looking for different, but interrelated objectives. The aim of the first stage was to identify bybrid socio-economic models in the pool of socio-economic organizations: social enterprises, cooperatives and non-profit organizations, in order to observe main areas of intersection among social and economic action logics. The hypothesis formulated for the first stage of the research: Hypothesis 1: Innovative hybrid socioeconomic models emerge from intersection of social and economic action logics through multiple organisational domains.

The aim of the second stage of the research was to identify typical characteristics of socio-economic ecosystems and to see correlation between the ecosystem patterns and development of hybrid socioeconomic models among enterprises. The hypothesis formulated for the second stage of the research: 
Hypothesis 2: There is a relation between socio-economic ecosystems` hybridity and development of hybrid socio-economic models among organisations.

\subsection{The first stage of the research. Hybrid models}

The identification of hybrid socio-economic models was implemented using multilevel identification, the final sample formed through sequential stages: randomly selected organisations $\rightarrow$ pool of socioeconomic organisations (non-governmental organizations and social enterprises) $\rightarrow$ social enterprises $\rightarrow$ hybrid models. The narrowing of the target sample was implemented using different methods: public data analysis $\rightarrow$ questionnaire $\rightarrow$ interview $\rightarrow$ case analysis, see figure 2 .

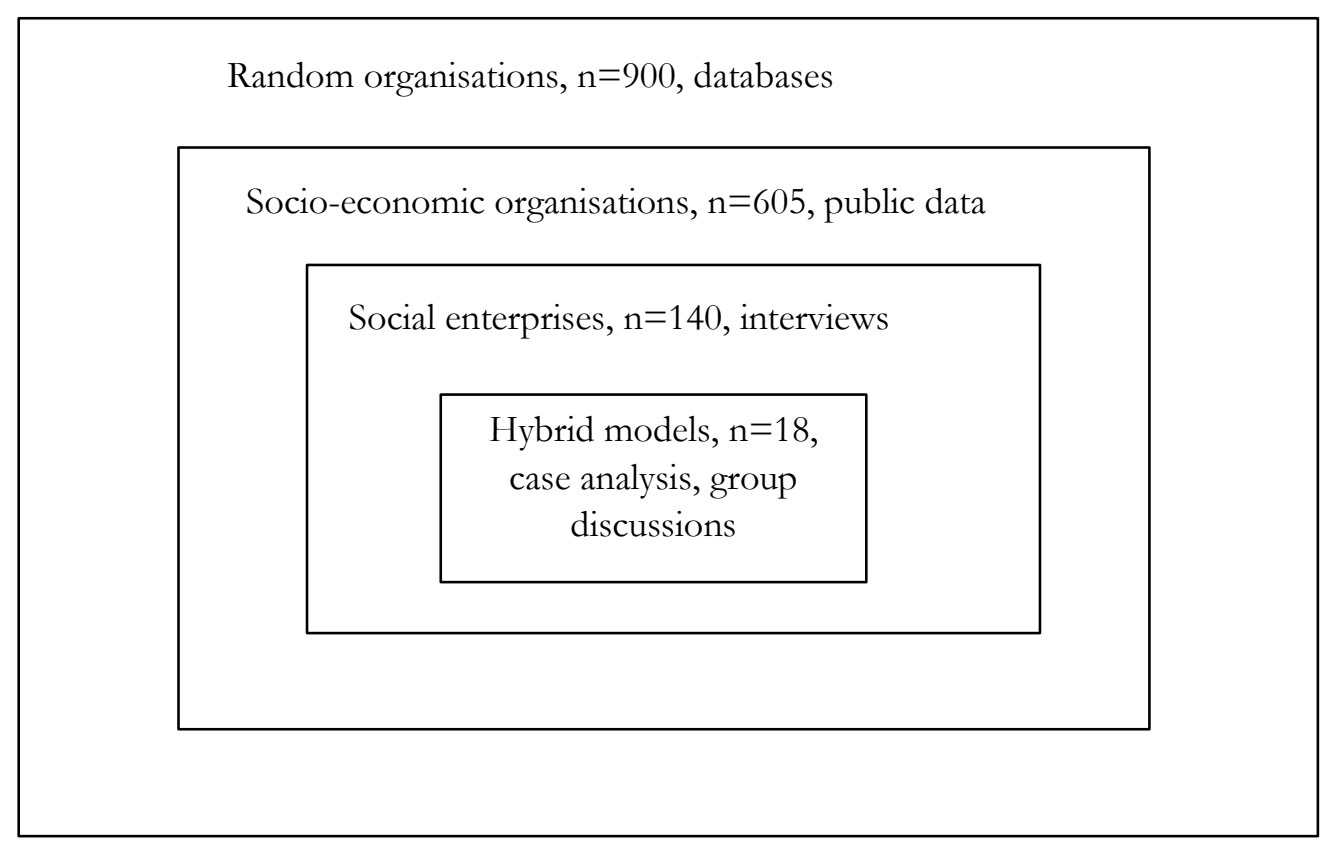

Figure 2. The structure of research

Source: compiled by authors

The research was conducted in three countries Lithuania, Latvia and Ukraine. Lithuania and Latvia are European Union member states, and Ukraine is not. These countries were selected, because from the superficial view all three countries, especially Latvia and Lithuania seem similar, hence the analysis of social enterprise development highlights significant differences. The deeper investigation of the conditions underlying the variance leads to insights around the social enterprise ecosystem characteristics.

The total amount of organizations included into the research was 900 of them 498 organizations from Lithuania, 214 from Latvia and 188 from Ukraine. These organizations were selected from the national online databases of social enterprises and non-governmental organizations: Latvian organizations were selected from the official register of social enterprises at the Ministry of Welfare and the Latvian association of social enterprises; Ukrainian organizations were selected from the catalogue managed by the social enterprise platform "Social business in UA", Lithuanian organizations were collected from the Centre of Registers and the database of work integration social enterprises at the Ministry of Social Security and Labor and Nongovernmental organizations' information and support center.

At the first stage we analysed web pages and public profiles in social media of the organizations and selected 605 (margin of errors $\pm 2 \%$ ), which showed applying social mission and commercial activities. The 
population of the selected organisations encountered non-profit organisations by their legal form (NPO), such as charities, associations, civil organisations and etc., and for-profit organisations (PO), such as work integration social enterprises, limited liability enterprises, which identify themselves as social enterprises (see the table 2 ).

At the second stage all the selected organisations were asked to answer the on-line questionnaire, the response rate was $61.7 \%$ (373). The questionnaire combined open and closed questions and were organized around three domains of inquiry: combination of social aim with economic activities; structure of personnel; stakeholders' involvement:

1. Whether organisation's primal purpose is to reach social impact? What is this impact?

2. Whether organisation implement constant economic activities?

3. Does organisation generate incomes from economic activities?

4. Whether organisation attracts subsidies, grants, donations or charity?

5. What percent from total income is generated from subsidies, grants or charity and what percent of income is generated from economic activities?

6. Whether organisation has employed staff?

7. Does organisation engage volunteers?

8. Does organisation engage stakeholders into decision making? How stakeholders are involved?

9. Does organisation provide financial, activity or impact reports to stakeholders? What kind of reports?

Table 2

The structure of researched organisations

\begin{tabular}{|l|l|l|l|l|}
\hline \multicolumn{2}{|c|}{ Organisations researched } & \multicolumn{1}{|c|}{ Lithuania } & \multicolumn{1}{|c|}{ Latvia } & \multicolumn{1}{c|}{ Ukraine } \\
\hline Number of socio-economic organisations & 348 & 150 & 107 \\
\hline \multirow{2}{*}{ Of them } & NPO & $210(60.3 \%)$ & $136(90.7 \%)$ & $72(67.3 \%)$ \\
\cline { 2 - 5 } & PO & $138(39.7 \%)$ & $14(9.3 \%)$ & $35(32.7 \%)$ \\
\hline Number of social enterprises identified & $88(25.3 \%)$ & $28(18.7 \%)$ & $24(22.4 \%)$ \\
\hline Number of hybrid socio-economic models & $10(2.9 \%)$ & $4(2.6 \%)$ & $4(3.7 \%)$ \\
\hline
\end{tabular}

Source: compiled by authors

At the third stage, after analysing the results of questionnaires, $140(23 \%)$ organisations were selected because they combined social goals with constant economic activities and engaged stakeholders. $122(87,2 \%)$ organisations were identified as social enterprises and $18(12,9 \%)$ of them were identified as hybrid, because they integrated social and economic logics on more than 3 out of 6 domains: legal form, goals, incomes, customers, activities, employees, see table 3.

At the fourth stage of the research 18 hybrid organisations were interviewed for in depth case analysis. These organisations showed deep integration of social and economic logics through number of domains and developed innovative and unique combinations into hybrid socio-economic business models. 
Hybrid socio-economic models

\begin{tabular}{|l|l|l|l|l|l|l|}
\hline $\begin{array}{l}\text { Number of domains } \\
\text { with integration of }\end{array}$ & 1 of 6 & 2 of 6 & 3 of 6 & 4 of 6 & 5 of 6 & 6 of 6 \\
\cline { 2 - 7 } $\begin{array}{l}\text { social and economic } \\
\text { logics }\end{array}$ & $\begin{array}{l}\text { Socio-economic models, representing light or } \\
\text { moderate integration of social and } \\
\text { economic logics }\end{array}$ & $\begin{array}{l}\text { Hybrid socio-economic models, representing high } \\
\text { integration of social and economic logics }\end{array}$ \\
\hline $\begin{array}{l}\text { Number of } \\
\text { organisations (n-140) }\end{array}$ & $61(43,6 \%)$ & $33(23.6 \%)$ & $28(20 \%)$ & $10(7.1 \%)$ & $6(4.3 \%)$ & $2(1,4 \%)$ \\
\hline
\end{tabular}

Source: compiled by authors

The data for case analysis of hybrid socio-economic models was collected through loosely structured 26 group interviews. We executed 2 group conversations in each hybrid organization: one group interview involved shareholders, founders, and management, the second interview was dedicated to employees and beneficiaries. The case studies were formed from content analysis of the group interviews. The aim of case analysis was to understand the mode of development of hybrid socio-economic models and their characteristics. Overview of the hybrid socio-economic models is presented in the table 4 .

The case analysis involved collection of information around these themes:

1. The mode of creation of the socio-economic model.

2. The types of recipients.

3. The access to markets strategies.

4. The mechanism of scaling adopted.

5. The membership and governance model.

6. The business model adopted.

7. The key partners.

8. The financing mechanisms.

9. The main barriers and support factors

10. The organisations' relationship to ecosystem and characteristics of national socio-economic ecosystem.

Table 4

Description of hybrid socio-economic models

\begin{tabular}{|c|c|c|}
\hline Hybrid business model & $\begin{array}{ll}\begin{array}{l}\text { Number } \\
\text { organisations }\end{array} & \text { of } \\
\end{array}$ & Summary of business model \\
\hline Work integration social enterprise & 6 & $\begin{array}{l}\text { Employ, educate and provide various social and } \\
\text { psychological support and development services to } \\
\text { disadvantaged persons, which are engaged in } \\
\text { organisations economic activities. }\end{array}$ \\
\hline Services to disadvantaged people & 4 & $\begin{array}{l}\text { Part of services, designed to the market are adopted } \\
\text { and provided to disadvantaged persons. (e.g., Social } \\
\text { taxi). }\end{array}$ \\
\hline $\begin{array}{l}\text { Non-financial and/or financial } \\
\text { support to social aim } \\
\text { organisations }\end{array}$ & 3 & $\begin{array}{l}\text { Open work space, supported with consultancy and } \\
\text { access to micro credits to social aim organisations: } \\
\text { communities, social enterprises, civil organisations. }\end{array}$ \\
\hline Serving community needs & 3 & $\begin{array}{l}\text { Community owned enterprises: food production, local } \\
\text { tourism }\end{array}$ \\
\hline $\begin{array}{l}\text { Promotion of sustainable life, } \\
\text { duction of general society }\end{array}$ & 2 & $\begin{array}{l}\text { Workshop of recycled material, donation stores and } \\
\text { education-workshop spaces }\end{array}$ \\
\hline
\end{tabular}

Source: compiled by authors 


\subsection{The second stage of the research. Ecosystem assessment}

The aim of the second stage of the research was to identify typical characteristics of socio-economic ecosystems and to see correlation between the ecosystem patterns and development of hybrid socioeconomic models among enterprises. The hypothesis formulated for the second stage of the research: Hypothesis 2: There is a relation between socio-economic ecosystems ' hybridity and development of hybrid socio-economic models among organisations.

The data for socio-economic ecosystem was retrieved from case analysis group discussions and from national reports on social economy ecosystems. There were executed 26 interviews-discussions, which involved 144 stakeholders, of them $78(54.2 \%)$ representatives of socio-economic organisations, $33(22.1 \%)$ representing policy makers, $20(13.9 \%)$ groups of customers, 8 supporters $(5.5 \%), 5(3.3 \%)$ donors or investors. The national ecosystems were analyzed using comparative analysis of secondary data: Social enterprises and their ecosystem in Europe, Country report Lithuania, 2019; Social enterprises and their ecosystem in Europe, Country report Latvia, 2019; Pact. 2018. The Social Entrepreneurship Ecosystem in Ukraine: Challenges and Opportunities.

Socio economic ecosystems were analysed looking how social and economic actors, policies and action logics are integrated within 4 main social economy ecosystem's domains:

1. Actors. Which organisations (state, regional, private) are taking a lead role in social economy ecosystem development?

2. Relations. Which bottom up initiatives support social economy development: networks, associations, collaboration incentives, cross-institutional governance bodies?

3. Rules. What legal fiscal, and regulatory frameworks are in the country and how they support or limit development of social economy organisations?

4. Resources. What financing mechanisms, non-financing support, education and knowledge creation initiatives are active in the country and what is their role accelerating or limiting the development of social economy organisations?

The results of the analysis are presented in the article section 4. The analysis of socio-economic ecosystem characteristics was implemented using Hazenberg's typology ((Hazenber, 2016). The main attention of the research was focused on integration and tensions between social and economic domains of public and market relations/regulations and the intersection of top-down and bottom-up incentives through various areas of the ecosystem.

\section{EMPIRICAL RESULTS AND DISCUSSION}

\subsection{Hybridity in social enterprise models}

The research showed that socio-economic hybridity manifests differently through various combinations of the mentioned factors. The hybridity can cover all key aspects of the organization's behavior or can manifest in few of them, the intensity of hybridity also can be different, from the full amalgamation of dualities to negotiated links, thus forming a broad variety of different types (Alter, 2007; Grassl, 2012) of social enterprises. The forms and intensity of hybridity may flexibly shift interaction to external and internal feedback loops or developmental stage of the enterprise.

The interplay of social and economic logic within a social enterprise was analyzed referring to five factors, which are detailed in figure 1.: motive, assets, accountability, governance, and surplus. Some social enterprise, like charity shops, has clear integration of social, economic values in the motives factor, but poorly combine other assets' logic. Work integration model social enterprise ("Regseda"), established by the association of persons with disabilities to create workplaces, has a unilateral motive, seeks the social value 
exclusively, hence the asset structure combines market revenues with state subsidies. Researched hubs and incubators ("Impact hub Odessa," "Green Hub," "Domus Solis") collide social and economic motives, assets and surplus characteristics, but for governance and accountability apply business-like structures. Community social enterprise ("Budraičiai community,“ „Brožiai community") apply open and democratic governance structures and combine social and business logic in asset and surplus distribution activities.

The research identified, that interplay of social and economic logic is more frequent in motives, assets and surplus areas, comparing to governance and accountability. 8\% (16) social enterprises combine subsidies, grants; volunteers work with incomes from sales of goods or services. However, the preferences toward one or another financial source were observed more often than efforts to find the balance. Some social enterprises treat grants and subsidies as a priority source of financing and market incomes as a supplementary independent source, the others - apply to grants on temporary base for particular projects, investments to infrastructure or capacity building. Only one social enterprise Impact Hub Odessa was significantly relying on the investors (founders), seven social enterprises generated dominant part of incomes from market activities, and for 11 social enterprises, the main source of assets are grants, subsidies or donations.

In the motives area, $1 / 3$ of social enterprises combined social and economic incentives. They officially state and at the mode of creation institutionalized in founding documents the combination of market and social missions. A typical combination of market and social goals is through enhancement of social impact as a priority goal and humbling market activities as an instrument to generate incomes. $2 / 3$ of social enterprises as their main goal point out the exclusively social value or social impact.

Social enterprises mentioned the importance of accountability to stakeholders or involvement of stakeholders into co-production of services in 10 cases. All observed social enterprises carried out obligatory accountability to shareholders, investors, donors or regulatory institutions. Hence, more often social enterprises engage with stakeholder when their services are targeted to disadvantaged people because a better understanding of specific customer's behavior and needs help to accommodate services.

The research identified a direct link between accountability and governance factors. The organizations with more democratic governance, members councils, boards, and committees are more likely to involve stakeholders into decision making and co-production. $50 \%$ of the researched social enterprises had "closed" corporate governance, were the leading decision maker is $\mathrm{CEO}$, who usually is a founder of the organization, four organizations had active boards, and 5 had a more complex structure, with various boards, councils, members conferences, etc.

Evaluation of hybridity within the surplus distribution factor included assessment if particular social enterprise distributes the profit to shareholders, social beneficiaries or reinvest to business development. The study discovered that $2 / 3$ of social enterprises reinvested all or the major share of the profit to business development: mainly renovation or acquisition of the infrastructure or competence development. Two social enterprises changed their strategies: at the beginning, they reinvested all the profit into business development, and later started to distribute part of the surplus to social value creation. Few social enterprises, who historically were charity organizations, distribute all the surplus to the social beneficiaries and does not invest in business development, resource acquisition or competence building.

The research identified that reinvestment of larger share of surplus does not always designate the prevalence of social value against financial, because the redistribution of profit can be organized through bonuses or other forms. The social enterprise which distributes all the surplus to social beneficiaries claimed to bound the enterprise future sustainability and growth opportunities for the social mission.

The presented snapshot of analyzed social enterprises, to above-mentioned characteristics, shows a high variety of combinations, which makes difficult and misleading to apply the rigid definition of social enterprise criteria. 
The compound of different hybrid socio-economic characteristics is significant to identify the social enterprise model. On the other hand, a variety of combinations reflect the dynamic nature of the social enterprise business model, which adapts and changes over time and conditions.

\subsection{Hybridity as a developmental process}

To understand behavioral patterns and trends of social enterprise, following the system thinking approach (Meadow, 2008), we added time perspective to the exploratory case analysis, to observe how social and economic logics interplay through historical, social enterprise development. The historical analysis unveiled three general patterns: 1) Social enterprise transform their model adjusting to changing customer needs and legal environment 2) hybrid social enterprise model often was not predefined at the mode of establishment but formed through developmental journey reacting to external and internal risks and opportunities; 3) ability to flexibly manipulate social and economic logic and institutional structures assures efficiency and sustainability of the social enterprise.

Out of 18 observed social enterprises, seven had operated more than ten years, nine were active for more than five years, and two were at the start-up stage. All the organizations with the history of more than ten years had overcome through major transformations, that comprised change of the business model, customer segments, governance structure, even legal form or goals. All the major transformations were preceded by financial or human resource crisis and stimulated by mentors or external consultants.

The cross-case analysis showed that through the years, social enterprise model generally shifts like a pendulum, swinging and balancing between two polarities - business model, focusing of efficiency and profit, and non-profit charity model aiming to create social value. When a social enterprise leans too much to the business side, it intensifies the risk of the commodification of social value. Then to balance the risk, it moves to the charity side, where the loss of qualified resources and financial sustainability. The search for equilibrium leads to hybrid socio-economic model development (Powell et al., 2018; Bowens et al., 2020). Such observations lead to the assumption, that the hybrid model linked to social enterprise identity is not a precondition, but a goal. This insight is important for financial support instruments, legal framework, and social enterprise evaluation and entitlement mechanisms.

The countries like Lithuania and Latvia that do not have long-lasting social enterprise history, and recently adopt legal frameworks for social enterprise, define them as a different and separate economic entity (European Commission, 2015; European Commission, 2018). Hence our research shows that social enterprise often develops from non-profit organizations or business enterprises when they transform the initial business model.

Empirical research showed that the main leverage points (Meadow, 2008) for the transformation of the non-profit organization toward social enterprise hybrid are related to assets management and governance. Non-profit social enterprise at the beginning of activities relies on external financing in forms of grants, subsidies or donations. Through time dissatisfaction with grants or subsidies intensifies due to bureaucracy and operational limitations and organization's seeks to gain financial independence as well as decision making autonomy through sales of goods and services. Hence, the lack of competence and start-up investment procrastinate the movement toward entrepreneurial activities.

Business enterprises lean toward social enterprise hybrid model because of the shift in shareholders values and motives. The integration of social purpose helped to overcome the loss of meaning as well as finance and creative descend. For example, Ukrainian craft workshop Woodluck, after a study visit to social enterprises got inspiration to make a broader impact on society through their activities. The idea to start a social workshop and employ disadvantaged persons as well to share part of the surplus to charities was 
positively welcomed by employees; enterprise received grants for social enterprise activities and extended network of partners and product portfolio.

The legal limit for for-profit legal entities to apply for social subsidies or to attract volunteer workforce, is a barrier to hybrid socio-economic logic enhancement. On the other hand, if the state provides subsidies to social enterprise, business has a temptation to move toward social enterprise model due to financial gain, but not due to the motivation to create social impact. Research by Okuneviciute Neverauskiene, Moskvina (2011-2013) showed that first WISEs in Lithuania were mostly focused on the employment of people with disabilities, supporting their return to work and their social integration. Currently, these social enterprises operate with a rising focus on economic — rather than social—objectives.

Hence, the research identified, that social enterprise as a hybrid model does not fully fit none of the traditional structures, what makes this model challenging to navigate. On the other hand social enterprise are influenced by both economic and social systems and seek to combine opportunities emerging in both institutional arrangements and lead toward development of integrated social enterprise ecosystem.

\section{SOCIAL ENTERPRISE ECOSYSTEMS: POLARITIES AND PECULIARITIES}

Social enterprise ecosystems in Lithuania, Latvia, and Ukraine are undergoing transitions. All countries share a common history of post-soviet regime, hence particular cultural, political and legal environment influenced a very different state of social enterprise development. The research focused on the interplay of key ecosystem enablers (Jacobides, 2018) actors (state, regional, private), relations (networks, associations, collaboration incentives, cross-institutional governance bodies), rules (legal frameworks), resources (financing mechanisms, non-financing support, education and knowledge creation) and their role accelerating or limiting the development of social enterprise.

The research highlighted three common tensions influencing the national social enterprise ecosystems dynamic:

1) Centralized or decentralized, regional state interventions (Hazenber, 2016). Centralized state interventions mean that social enterprise sector is very reliant on state institutions policies and support, the acceleration mechanisms are implemented through legislative systems, such as institutionalization of particular legal form or status to social enterprise model, national financing programs and grants. Decentralized interventions mean that social enterprises build relations with local or municipal institutions and main instruments of financing are local or regional grants and public procurements.

2) Division of social and economic sectors and institutional logics or their socio-economic bybridity (Grassl, 2012). This tension manifests through power logics among the social enterprise ecosystem's actors. When the sectoral division is strong, social enterprises are either treated as nonprofit's generating incomes through trade, either traditional enterprises, creating social value. This division is expressed in the legal framework, barriers to financing, public policies and institutions involved, separate non-formal networks and general image. When socio-economic hybridity prevails, the ecosystem is characterized by cross-sectoral, cross-institutional collaboration, networks, policies, legal environment and financial instruments particularly oriented toward socioeconomic models. In such ecosystem, social enterprise model is not linked to particular legal form but can adopt any of the existing legal forms, and investors of financial mechanisms do not perceive social value creation as a compromise to business effectiveness and sustainability.

3) Civil society ability to self-organize or dependence on the state institutions (Defourny \& Nyssens, 2017; Qureshi et al., 2016). When society is highly dependent on the institutional arrangements and support there is a lack of private initiatives and public dialogue, networks are underdeveloped, and 
associations advocate their interests through lobbying. In such ecosystems, social enterprises blame the state for lack of attention and financing. Hence existing alternative resources (hubs, incubators, instruments of financial engineering) available in the market are not exploited. High level of selforganization express in a vast variety of small and large initiatives, self-help networks, private investments and funds, cross-sectoral and cross-institutional collaborations, a variety of social enterprise models.

Table 5 summarizes characteristics of social enterprise ecosystems in Lithuania, Latvia, and Ukraine following the above-mentioned tensions and Hazeberg's typology. The comparative analysis outlined that post-soviet countries have centralized nature of states and it reflects in high society dependence on state interventions and regulations. Hence, the case of Ukraine shows, that lack of state support as well regulations create space for private initiatives to emerge and to self-organize. The case of Lithuania unveils that social enterprise ecosystem development is effective when it combines bottom-up and top-down initiatives, hence scientific and applied research emphasizes the bottom-up approach (Jucevicius \& Grummadaite, 2014).

Table 5

Characteristics of national SE ecosystems by types of national regulation and SE sector government dependency

\begin{tabular}{|c|c|c|c|c|}
\hline Country & $\begin{array}{c}\text { State } \\
\text { interventions }\end{array}$ & National regulation & $\begin{array}{l}\text { Government } \\
\text { dependency }\end{array}$ & $\begin{array}{l}\text { Hazenberg's } \\
\text { typology }\end{array}$ \\
\hline Lithuania & $\begin{array}{l}\text { Centralized. } \\
\text { State subsidies to } \\
\text { work integration } \\
\text { social enterprises } \\
\text { International } \\
\text { funds. }\end{array}$ & $\begin{array}{l}\text { Fragmented integration of social } \\
\text { and economic sectors. } \\
\text { Cross-sectoral collaboration } \\
\text { of policy-makers. } \\
\text { Legal definition of a hybrid } \\
\text { socio-economic model. } \\
\text { A mixture of non-profit and } \\
\text { for-profit legal forms. }\end{array}$ & $\begin{array}{l}\text { SE sector dependence on } \\
\text { state institutions is } \\
\text { supported with weak } \\
\text { capacity to self-organize. } \\
\text { No active networks, } \\
\text { associations. } \\
\text { Partnership or } \\
\text { investment initiatives } \\
\text { are fragmented and } \\
\text { dependent on } \\
\text { international or state } \\
\text { grants. }\end{array}$ & $\begin{array}{l}\text { Type A Statist- } \\
\text { Macro. }\end{array}$ \\
\hline Latvia & $\begin{array}{l}\text { Centralized. } \\
\text { Public support } \\
\text { based on } \\
\text { European Union } \\
\text { funds. }\end{array}$ & $\begin{array}{l}\text { Strong division of social and } \\
\text { economic sectors. } \\
\text { Belong to social policy. } \\
\text { Since } 2018 \text { a hybrid socio- } \\
\text { economic model is } \\
\text { institutionalized. Prevail } \\
\text { non-profit legal forms. }\end{array}$ & $\begin{array}{l}\text { SE sector dependence on } \\
\text { state institutions is lessened } \\
\text { by capacity to self-organize. } \\
\text { Active social } \\
\text { entrepreneurship } \\
\text { association of Latvia. A } \\
\text { partnership among } \\
\text { different networks. }\end{array}$ & $\begin{array}{l}\text { Type A Statist- } \\
\text { Macro. }\end{array}$ \\
\hline Ukraine & $\begin{array}{l}\text { Decentralized. } \\
\text { Local private } \\
\text { inititatives, } \\
\text { international } \\
\text { donors grants. }\end{array}$ & $\begin{array}{l}\text { Strong division of social and } \\
\text { economic sectors. } \\
\text { No institutionalized socio- } \\
\text { economic model. Prevail } \\
\text { non-profit legal forms. }\end{array}$ & $\begin{array}{l}\text { SE sector is strongly } \\
\text { independent form state } \\
\text { institutions. } \\
\text { Variety of private hubs, } \\
\text { incubators, networks, } \\
\text { platforms, self-help } \\
\text { communities. Prevail in } \\
\text { non-profit legal forms. }\end{array}$ & $\begin{array}{l}\text { Type D - Private } \\
\text { Micro. }\end{array}$ \\
\hline
\end{tabular}

Source: compiled by authors

Understanding and appreciation of the systemic patterns manifested in particular national or regional ecosystem are valuable to understand what interventions enable social enterprise ecosystem development in the national or regional level. The enhancement of cross-sectoral collaboration, expansion of local support 
mechanisms, promotion of public and private partnership through public procurement of social services as well as institutional support to social enterprise networks could be a prospective incentive for systemic development of social enterprise ecosystem in Lithuania and Latvia. However the Ukrainian social enterprise ecosystem can get more inspiration and support through partnership and collaboration with international private foundations, social investment funds or global networks such as Ashoka.

The comparative analysis of national social enterprise ecosystems highlighted the need for balance between bottom-up and top-down incentives. Lithuania, Latvia, and Ukraine or other countries that show relatively low capacities of society to self-organize and form structural changes from bottom-up, require stimulus form the state or international organizations to create enabling social enterprise ecosystems.

Figure 3 illustrates polarity tensions and area of hybridity for social enterprise ecosystem development on strategic tactical levels. If the conflict of strategic priorities is solved and socio-economic hybridity is acknowledged on the highest policy level, tactical mechanisms will be cross-sectoral and in fuel systemic innovations enabling long-lasting ecosystem development.

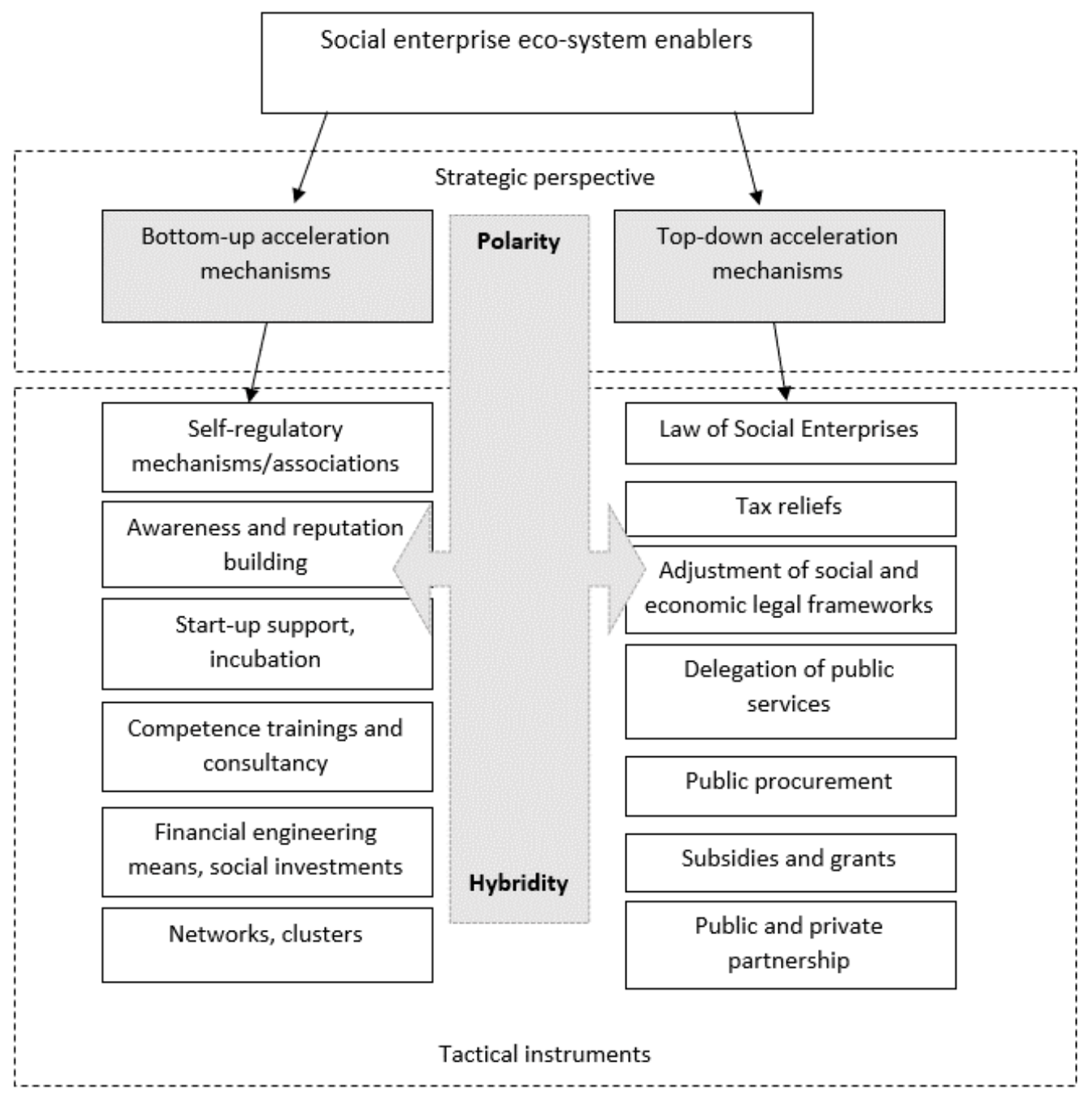

Figure 3. Strategic and tactical social enterprise ecosystem enablers

Source: Compiled by authors 
From the international policy-making sense, the peculiarities of the national ecosystems highlight request for more flexible and adaptable international policy and funding strategies aiming to support social enterprise development in the heterogeneous organic way. Shvedovsky, Standrik and Bilan, 2016 underline, that transition from simple to complex systems is carried out through innovations, "and the complexity of these inventions correspond to complexity of society development level” (Shvedovsky, 2016:139). Hence, social enterprise ecosystem research has a great applied value, preventing policymakers from ineffective or non-timely interventions and helping to understand the strategic development perspectives appreciating national and regional peculiarities.

\section{CONCLUSION}

The research identifies, that hybridity is a significant factor to social enterprises and social enterprise ecosystem identity and development. The hybridity has a direct relation to sustainability, innovativeness, and efficiency of the social enterprises. The hybridity can cover all key aspects of the organization's behavior or can manifest in few of them, the intensity of hybridity also can be different, thus forming a broad variety of different types of social enterprise models. The hybridity is dynamic quality; it may flexibly shift reacting to external and internal feedback loops or developmental stage of the enterprise. Therefore, any rigid definition of eligibility characteristics to social enterprise applied by donors, legal frameworks or entitlement procedures don't picture the living variety of social enterprise species, contrary, - they force the social enterprise to adjust their natural behavior to fit in the theoretical framework.

The article argues for an alternative approach, that social-economy hybridity is not a predominant model to social enterprise, but a process and a goal of development. The study showed that social enterprise transforms their model adjusting to changing customer needs and legal environment; hybrid social enterprise model often was not predefined at the mode of the establishment but formed through developmental journey reacting to external and internal risks and opportunities. Such an approach offers a common ground around a variety of legal forms and threshold requirements, negotiated by social entrepreneurs and social investors.

The analysis of-of four national social enterprise ecosystems unveiled three general characteristics, enabling or limiting systemic social enterprise development: level of governance centralization, societies ability to self organize and socio-economic hybridity. In social enterprise ecosystems, strong hybridity enhances the supportive environment to social enterprise sector development through cross-sectoral collaboration.

Different combinations of the characteristics form particular patterns of the national eco-systems, which influence social enterprise preferred models and behavior. In countries with high governance centralization and limited abilities of society to self-organize social enterprise expect top-down incentives. In the ecosystem with high level of governance centralisation, but strong societies abilities to self-organize, initiatives emerge in the bottom-up manner, but are fragmented and localized.

The peculiarities of the national ecosystems highlights request for more flexible and adaptable international policy and funding strategies aiming to support social enterprise development in the organic heterogeneous way. The support instruments with rigid and narrow social enterprise definitions, specific goals oriented or eligible to certain enterprise models limit social enterprise developmental abilities. Hence, social enterprise ecosystem research has a great applied value, preventing policy makers from ineffective or non-timely interventions and helping to understand the strategic development perspectives appreciating national and regional peculiarities. 


\section{REFERENCES}

Adner, R. (2012). The Wide Lens: a New Strategy for Innovation. Portfolio Penguin.

Adner, R. (2016). Ecosystem as structure: an actionable construct for strategy. Journal of Management, 43(1). doi:10.1177/0149206316678451

Adner, R., \& Feiler. D. (2017). Innovation Interdependence and Investment Choices: an Experimental Approach to Decision Making Ecosystem. Unpublished results.

Agafonow, A. (2014). Toward a positive theory of social entrepreneurship. On maximizing versus satisficing value capture. Journal of Business Ethics, 125, 709-713.

Alter, K (2007). Social Enterprise Typology. Virtue Ventures LLC.

Artcer, T., Chayka, Y., \& Trukhanenko, A. (2016). Mentoring as an Essential Element of Social Entrepreneurship. WELLSO III International Scientific Symposium on Lifelong Wellbeing in the World, 34-42. http://dx.doi.org/10.15405/epsbs.2017.01.5

Audretsch, D.B. (2010) Sustaining innovation and growth: public policy support for entrepreneurship. Industry and Innovation, 11, 167-191. https://doi.org/10.1080/1366271042000265366

Battilana, J., \& Lee, M. (2014). Advancing Research on hybrid organizing - Insights from the study of social enterprises. The Academy of Management Annals, 8(1), 397-441. doi: 10.1080/19416520.2014.893615

Bauwens, T., Huybrechts, B., \& Dufays, F. (2020). Understanding the diverse scaling strategies of social enterprises as hybrid organizations: the case of renewable energy Cooperatives. Organization \& Environment, 33(2), 195-219.

Bretos, I., Bouchard, M. J., \& Zevi, A. (2020). Institutional and organizational trajectories in social economy enterprises: resilience, transformation and regeneration. Annals of Public and Cooperative Economics, 91(3), 351-357.

Besley, T., \& Ghatak, M. (2017). Profit with purpose? A theory of social enterprise. American Economic Journal: Economic Policy, 9(3), 19-58. doi: 10.1257/pol.20150495

Bilan, Y., Mishchuk, H., \& Pylypchuk, R. (2017). Towards sustainable economic development via social entrepreneurship. Journal of Security and Sustainability Issues, 6(4), 691-702. http://doi.org/10.9770/jssi.2017.6.4(13)

Blundel, R., \& Lyon, F. (2015). Towards a long view: historical perspectives on the scaling and replication of social ventures. Journal of Social Entrepreneurship, 6(1), 80-102.

Borzaga, C., Fazzi, L., \& Galera, G. (2016). Social enterprise as a bottom-up dynamic: part 1. The reaction of civil society to unmet social needs in Italy, Sweden and Japan. International Review of Sociology, 26(1), 1-8. doi: 10.1080/03906701.2016.1148332

Conger, M., McMullen, J.S., Bergman, J.B., \& York, G.J. (2018). Category membership, identity control, and the reevaluation of prosocial opportunities. Journal of Business Venturing, 33(2), 179-206. doi: https://doi.org/10.1016/j.jbusvent.2017.11.004

Cornelissen, J.P., Akemu, O., Jonkman, J. G.F., \& Werner, M. D. (2020). Building character: the formation of a hybrid organizational identity in a social enterprise. Journal of Management Studies, 1-37. doi:10.1111/joms.12640

Dedeurwaerdere, T., De Schutter, O., Hudon, M., Mathijs, E., Annaert, B., Avermaete, T., Bleeckx, Th., de Callataÿ, Ch., De Snijder, P., Fernández-Wulff, P., Joachain, H., \& Vivero, J.L. (2017). The governance features of social enterprise and social network activities of collective food buying groups. Ecological Economic, 140, 123135.

Defourny, J., \& Nyssens, M. (2010). Conceptions of social enterprise and social entrepreneurship in Europe and in the United States: convergences and differences. Journal of Social Entrepreneurship, 1(1), 32-53.

Defourny, J., \& Pestoff, V. (2014). Towards a European conceptualization of the third sector. In (Ed.) Accountability and Social Accounting for Social and Non-Profit Organizations (Advances in Public Interest Accounting, Volume 17) (pp. 25-87). Bingley, United Kingdom: Emerald Group Publishing Limited. doi: https://doi.org/10.1108/S1041-706020140000017001

Defourny, J., \& Nyssens, M. (2017). Fundamentals for an international typology of social enterprise models. International Journal of Voluntary and Nonprofit Organizations, 28, 2469-2497. doi: https://doi.org/10.1007/s11266-017-9884-7

Dinçer, H., Yüksel, S., Korsakienè, R., Raišienė, A.G., \& Bilan, Y. (2019). IT2 Hybrid decision-making approach to performance measurement of internationalized firms in the Baltic States. Sustainability, 11, 296, 1-22. 
Eisenhardt, K.M. (1989). Building theories from case study research. Academy of Management Review, 14(4), 532-550.

Eldar, O. (2017). The role of social enterprise and hybrid organizations. Columbia Business Law Review, 92-194. doi: http://dx.doi.org/10.2139/ssrn.2379012

Garrow, E.E., Hasenfeld, Y. (2014). Social enterprise as an embodiment of a neoliberal welfare logic. American Behavioral Scientist, 58(11), 1475-1493. doi: https://doi.org/10.1177/0002764214534674

European Commission. (2018). Social enterprises and their ecosystems in Europe. Updated country report: Latvia. Autor Lasma Licite.

European Commission. (2018). Social enterprises and their ecosystems in Europe. Updated country report: Lithuania. Authors Okuneviciute-Neverauskiene, L., Pranskeviciute I.

European Union. (2015). A map of social enterprises and their eco-systems in Europe: Synthesis report. Luxembourg: Publications Office of the European Union.

Galera, G., \& Borzaga, C. (2009). Social enterprise: An international overview of its conceptual evolution and legal implementation. Social Enterprise Journal, 5(3), 210-228.

Grassl, W. (2012). Business models of social enterprise: a design approach to hybridity. ACRN Journal of Entrepreneurship Perspectives, 1(1), $37-60$.

Hazenberg, T., Bajwa-Patel, M., Mazzei, M.J., \& Baglioni, S. (2016). The role of institutional and stakeholder networks in shaping social enterprise ecosystems in Europe. Social Enterprise Journal, 12(3), 302-321.

Hoffman, A.J., Badiane, K.K., \& Haigh, N. (2012). Hybrid organizations as agents of positive social change: bridging the for-profit \& non-profit divide. Working Paper No. 1149. In K. Golden-Biddle and J. Dutton (Eds.) Using a Positive Lens to Explore Social Change and Organizations: Building a Theoretical and Research Foundation (pp. 1-30). Routledge, Taylor and Francis Group.

Kim, D., Cho, W., \& Allen, B. (2020). Sustainability of social economy organizations (SEOs): an analysis of the conditions for surviving and thriving. Social Science Journal, 1-17.

Kochlami, H., Davidsson, P., Obschonka, M, Yazdanfar, D., \& Lundstrom, A. (2020). The regional employment effects of new social firm entry. Small Business Economics. doi: 10.1007/s11187-020-00345-9

Kwona, H., Choia, Y. \& Lamb, B. (2018). The design and social enterprise ecosystem: How can design be applied to a developing social enterprise ecosystem? Design Research Society, 1-16. doi:10.21606/dma.2017.283

Marquis, Ch., \& Park, A. (2014). Inside the Buy-One Give-One Model. Stanford Social Innovation Review. Leland Stanford Junior University. Retrieved from http://www.people.hbs.edu/cmarquis/inside_the_buy_one_give_ one_model.pdf

Iansiti, M., \& Levien, R. (2006). The keystone advantage: what the new dynamics of business ecosystems mean for strategy, innovation, and sustainability. Academy of Management Executive, 20(2). doi: 10.5465/AMP.2006.20591015

Jacobides, M.G., Cennamo, C., \& Gawer, A. (2018). Towards a theory of ecosystems. Strategic Management Journal, 39, $2255-2276$.

Jucevicius, G., \& Grumadaite, K. (2014). Smart development of an innovation ecosystem. Procedia- Social and Behavioral Sciences, 156(26), 125-129.

Maier, F., Meyer, M., \& Steinbereithner, M. (2016). Nonprofit organizations becoming business-like: a systematic review. Nonprofit and Voluntary Sector Quarterly, 45(1), 64-86.

Martin, R., \& Osberg, S. (2015). Two keys to sustainable social enterprise. Harvard Business Review, 93(5), 86-93.

Mason, Ch., \& Moran, M. (2018). Social enterprise and policy discourse: a comparative analysis of the United Kingdom and Australia. Policy \& Politics, 46, 607-626. doi https://doi.org/10.1332/030557317X15133530312516

McMullen, J. (2018). Organizational hybrids as biological hybrids: Insights for research on the relationship between social enterprise and the entrepreneurial ecosystem. Journal of business venturing, 33, 575-590.

McMullen, J. \& Bergman, B. (2017). Social entrepreneurship and the development paradox of prosocial motivation: a cautionary tale. Strategic Entrepreneurship Journal, 11(3), 243-270. doi: 10.1002/sej.1263

Meadow, H.M., \& Wright, D. (2008). Thinking in Systems: A Primer. Chelsea Green Publishing.

O'Byrne, D., Lean, J., Moizer, J., Walsh, P., Dell'Aquila, E., \& Friedrich, R. (2014). Social enterprise in the European Union: A review of policy. Social \& Public Policy Review, 9(1), 13-29. 
Okuneviciute Neverauskiene, L., \& Moskvina, J. (2011). Social enterprises: aspect of social economy development. Philosophy. Sociology, 22(4), 384-393.

Pact. (2018). The Social Entrepreneurship Ecosystem in Ukraine: Challenges and Opportunities. Kyiv, Ukraine and Washington, DC: Pact.

Peltoniemi, M., \& Vuori, E. (2004). Business ecosystem as the new approach to complex adaptive business environments. Proceedings of eBusiness Research Forum, 1-15.

Powell, M., Gillett, A., \& Doherty, B. (2018). Sustainability in social enterprise: hybrid organizing in public services. Public Management Review 21(35). doi: 10.1080/14719037.2018.1438504

Pratono, H.A., \& Sutanti, A. (2016). The ecosystem of social enterprise: Social culture, legal framework, and policy review in Indonesia. Pacific Science Review B: Humanities and Social Sciences, December, 1-7. doi: 10.1016/j.psrb.2016.09.020

Ridley-Duff, R., \& Bull, M. (2016). Understanding Social Enterprise: Theory and Practice (2nd ed.). London: SAGE Publications Ltd.

Roy, M. J., McHugh, N., Huckfield, L., Kay, A., \& Donaldson, C. (2015). The most supportive environment in the world? Tracing the development of an institutional 'ecosystem' for social enterprise. Voluntas, 26(3), 777-800.

Shvedovsky, V., Standrik, A., \& Bilan, Y. (2016). Economic and social institutions: Modelling the evolution paths for the archaic society. Economics and Sociology, 9(2), 137-147. doi: 10.14254/2071-789X.2016/9-2/9

Signoretti, A., Sacchetti, S. (2020). Lean HRM practices in work integration social enterprises: moving towards social lean production. Evidence from Italian case studies. Annals of Public and Cooperative Economics, 91(4), 545-563.

Small, V., \& Rosandic, A. (2018). Social Economy in Eastern Neighbourhood and the Western Balkans. Country Report - Ukraine. AETS Consortium.

Staicu, D. (2017). Policy framework and legal forms of social enterprise in Central and Eastern Europe. Proceedings of the $11^{\text {th }}$ International Conference on Business Excellence, 875-883. doi: 11. 10.1515/picbe-2017-0093

Szymanska, A., \& Jegers, M. (2016). Modeling social enterprises. Annals of Public and Cooperative Economics, 87(4), 501527.

Talmar, M., Walrave, B., Podoynitsyna, K.S., Holmström, J., \& Georges L. Romme, A. (2019). Mapping, analyzing and designing innovation ecosystems: The Ecosystem Pie Model. Long Range Planning, 1-9. doi. doi.org/10.1016/j.lrp.2018.09.002

Thornton, P., \& Ocasio, W. (2008). Institutional Logics. In: R. Greenwood et al. (Eds.) The Sage Handbook of Organizational Institutionalism (pp.99-129). Los Angeles: Sage.

Vickers, I., Lyon, F., Sepulveda, L., \& McMullin, C. (2017). Public service innovation and multiple institutional logics: The case of hybrid social enterprise providers of health and wellbeing. Research Policy, 46(10), 1755-1768. doi: http://dx.doi.org/10.1016/j.respol.2017.08.003

Wry T., \& York, J. G. (2017). An identity-based approach to social enterprise. Academy of Management Review, 42(3), 437460. http://dx.doi.org/10.5465/amr.2013.0506

Yin, R. (1994). Case Study Research: Design and Methods (2nd ed.). Beverly Hills, CA: Sage Publishing.

Zahra, A., \& Wright, M. (2016). Understanding the social role of entrepreneurship. Journal of Management Studies 53(4), 610-629. doi: 10.1111/joms.12149 